\title{
The neuropsychological impact of the CoVID-19 pandemic on the mental wellbeing of individuals - what have we learnt thus far
}

\author{
Rivona Harricharan ${ }^{1 *}$ and William Mark Uren Daniels ${ }^{2}$ \\ ${ }^{1}$ Department of Clinical Medicine, University of KwaZulu-Natal, South Africa \\ ${ }^{2}$ School of Physiology, University of Witwatersrand, South Africa
}

\begin{abstract}
The novel Corona virus disease (COVID-19) has escalated drastically to become a global pandemic. Here we review the impact of COVID-19 on the brain. The search string "coronavirus and brain" was typed in Google Scholar and PubMed to yield 31500 and 2044 results respectively. Based on these results the effects of COVID-19 on the brain are two-fold, both neuropathological and psychological in nature. SARS CoV-2 produces a range of non-specific neurological symptoms (headaches, nausea, vomiting, altered mental status, anosmia, neuropathy, delirium, cerebrovascular incidents, seizures, Guillain-Barré Syndrome, cranial nerve dysfunctions, viral and autoimmune encephalitis). Indirect effects of SARS CoV-2 on the brain reside in the practices imposed by lockdown regulations including quarantine and self-isolation. These practices have resulted in psychological manifestations including stress, anxiety and post-traumatic stress disorder-related symptoms in infected and uninfected individuals. While online counselling platforms, resilience-building programmes and cognitive behavioural therapy strategies have been established, more need to be implemented to reduce the impact of these practices.
\end{abstract}

\section{Introduction}

The novel Corona virus disease (COVID-19) originated in Wuhan, Hubei Province in China in November 2019. COVID-19 is the result of infection with the positive-sense single stranded Severe Acute Respiratory Distress Syndrome Corona Virus-2 (SARS CoV-2). It escalated drastically to become a global pandemic with more than 124.8 million people infected with SARS CoV-2 and yielding a death toll of more than 2.74 million by March 2021 [1]. COVID-19 has spread to affect over 213 countries with the greatest number of cases being reported in the United States. To deal with the pandemic, all efforts and resources have been dedicated to mapping the geographic spread, genomics, transmissibility, clinical features, and treatment of COVID-19 [2]. While governments globally have implemented immediate action to contain the spread of SARS CoV-2 and limit the number of people infected, there has been minimal plans to address the mental health and any psychological issues originating from a catastrophe of this magnitude. The need for prompt action and prioritisation of appropriate healthcare services for those with underlying psychological and psychiatric vulnerabilities have been clearly identified [3-5].

Attempting to understand the neuropsychological implications of an infectious event of this scale warrants a multi-faceted approach [6]. Since pandemics of this nature occur so seldom, COVID-19 offers a unique opportunity to increase our understanding of the neuropsychological impact of such an event on the mental well-being of individuals and populations. The aim of this review therefore was to assess the status of current knowledge with respect to the neurological and psychological implications of COVID-19 and to suggest strategies that may be considered in future.

\section{Methods}

The search string "coronavirus and brain" was typed in Google Scholar and PubMed to yield 31500 results and 2044 results respectively. Articles published between the years 2019 and 2021 were of particular focus. The abstracts were screened for relevance to the topic of our literature review and the outcome revealed 53 studies focusing on COVID-19 and its related effects on the brain.

Based on the literature, COVID-19 has assigned the global population to two basic groups: those that are infected and those who are not. Each group faces their own neuropsychological consequences and biomedical challenges. This review will therefore first focus on the effects of the coronavirus on the brains of infected individuals and then on the impact of virus-related practices on the brains of uninfected individuals. Pooled descriptive statistics of the clinical data available for each group was evaluated (Table 1).

\section{COVID-19 and the Central Nervous System}

COVID-19 symptomology has not been limited to respiratory symptoms with some patients reporting neurological and psychiatric complaints (Table 1). Neuro-COVID is the term used to define the neuropathological manifestations following COVID-19 infection

*Correspondence to: Rivona Harricharan, Department of Clinical Medicine, University of KwaZulu-Natal, Durban, South Africa; E-mail: rivonah3@gmail.com

Key words: brain, corona virus, neuropathology, psychopathology, lockdown regulations, quarantine, self-isolation

Received: March 05, 2021; Accepted: March 30, 2021; Published: April 05, 2021 
Table 1. Review of neuropathological and neuropsychiatric findings.

\begin{tabular}{|c|c|c|c|c|c|c|}
\hline Study Title & n & $\begin{array}{l}\text { Mean } \\
\text { Age }\end{array}$ & Neuropathological Findings & Neuro-psychiatric Findings & $\begin{array}{l}\text { Mortality } \\
(\%)\end{array}$ & Reference \\
\hline $\begin{array}{l}\text { 1. Neurological and Neuropsychiatric complications of } \\
\text { COVID-19 in } 153 \text { patients: A UK-wide surveillance study }\end{array}$ & 153 & 71 & $\begin{array}{l}\text { CVA=77/125 (Ischaemic Stroke: 57/77; } \\
\text { ICH: } 9 / 77 \text { ) } \\
\text { CNS Vasculitis= } 1 / 77 \\
\text { Unspecified Encephalopathy= 9/39 } \\
\text { Encephalitis }=7 / 39\end{array}$ & $\begin{array}{l}\text { New onset Psychosis }=10 / 23 \\
\text { Neurocognitive syndrome }=6 / 23 \\
\text { Affective disorder }=4 / 23 \\
\text { AMS }=39 / 125\end{array}$ & NR & [23] \\
\hline $\begin{array}{l}\text { 2. Early Post-mortem brain MRI findings in COVID-19 non- } \\
\text { survivors }\end{array}$ & 19 & 77 & $\begin{array}{l}\text { Sub-cortical Micro- and Macro- } \\
\text { Hemorrhages }=2 / 19 \\
\text { Encephalopathy }=4 / 19\end{array}$ & & $\mathrm{P} / \mathrm{M}$ & [24] \\
\hline $\begin{array}{l}\text { 3. Guillain-Barré Syndrome following COVID-19: a newly } \\
\text { post-infectious complication }\end{array}$ & 1 & 57 & Guillain-Barré Syndrome= 1/1 & & $0 \%$ & [25] \\
\hline $\begin{array}{l}\text { 4. Brain MRI Findings in Severe COVID-19: A } \\
\text { Retrospective Observational Study }\end{array}$ & 37 & 61 & $\begin{array}{l}\text { Micro-Hemorrhages= 9/37. } \\
\text { ICH }=20 / 37\end{array}$ & $\mathbf{A M S}=27 / 37$ & $14 \%$ & [26] \\
\hline 5. Neuropathological Features of COVID-19 & 18 & 62 & Hypoxic injury $=18 / 18$ & & $\mathrm{P} / \mathrm{M}$ & [27] \\
\hline $\begin{array}{l}\text { 6. Guillain-Barré syndrome: The first documented COVID- } \\
\text { 19-triggered autoimmune neurologic disease }\end{array}$ & 11 & NR & Guillain-Barré Syndrome= 11/11 & & $9 \%$ & [28] \\
\hline $\begin{array}{l}\text { 7. Early evidence of pronounced brain involvement in fatal } \\
\text { COVID-19 outcomes }\end{array}$ & 6 & 69 & $\begin{array}{l}\text { Encephalitis }=5 / 6 . \\
\text { Lymphocytic } \text { Meningitis }=6 / 6 . \\
\text { Petechial Hemorrhages }=4 / 6 . \\
\text { Axon Degeneration }=3 / 6\end{array}$ & & $\mathrm{P} / \mathrm{M}$ & [29] \\
\hline $\begin{array}{l}\text { 8. Macrothrombosis and stroke in patients with mild } \\
\text { Covid-19 infection }\end{array}$ & 3 & 55 & $\operatorname{CVA}=3 / 3$ & & NR & [30] \\
\hline $\begin{array}{l}\text { 9. Acute Symptomatic Seizures in Critically Ill Patients with } \\
\text { COVID-19: Is There an Association? }\end{array}$ & 2 & 79 & Seizures $=2 / 2$ & & $50 \%$ & [31] \\
\hline $\begin{array}{l}\text { 10. Neuropathology of COVID-19: a spectrum of vascular and acute } \\
\text { disseminated encephalomyelitis (ADEM)-like pathology }\end{array}$ & 1 & 71 & $\begin{array}{l}\text { Acute disseminated encephalomyelitis }= \\
1 / 1\end{array}$ & & $100 \%$ & [32] \\
\hline $\begin{array}{l}\text { 11. COVID-19 related neuroimaging findings: A signal of } \\
\text { thromboembolic complications and a strong prognostic } \\
\text { marker of poor patient outcome }\end{array}$ & 38 & 64 & $\begin{array}{l}\text { CVA }=35 / 38 \text { (Ischaemic Stroke: } 26 / 38 ; \\
\text { ICH: } 9 / 38 \text { ) } \\
\text { Hypoxic injury }=2 / 38 \\
\text { Encephalitis }=1 / 38\end{array}$ & & $42 \%$ & [33] \\
\hline $\begin{array}{l}\text { 12. Prolonged Confusion state as first manifestation of } \\
\text { COVID-19 }\end{array}$ & 1 & 77 & & Confusion $=1 / 1$ & $100 \%$ & [34] \\
\hline $\begin{array}{l}\text { 13. COVID-19-associated meningoencephalitis complicated } \\
\text { with intracranial haemorrhage: a case report }\end{array}$ & 1 & 36 & Encephalitis and $\mathbf{I C H}=1 / 1$ & & $0 \%$ & [35] \\
\hline 14. Stroke in patients with SARS-CoV-2 infection: case series & 6 & 69 & CVA=6/6 (Ischaemic Stroke:4/6; ICH:2/6). & & $83 \%$ & [36] \\
\hline $\begin{array}{l}\text { 15. Miller Fisher Syndrome and polyneuritis cranialis in } \\
\text { COVID-19 }\end{array}$ & 2 & $\begin{array}{l}50 \\
39\end{array}$ & $\begin{array}{l}\text { Miller Fisher Syndrome }=1 / 1 \\
\text { Polyneuritis cranialis }=1 / 1\end{array}$ & & $0 \%$ & [37] \\
\hline $\begin{array}{l}\text { 16. EEG findings in acutely ill patients investigated for SARS- } \\
\text { CoV-2/COVID-19: A small case series preliminary report }\end{array}$ & 22 & 63 & Encephalopathy $=14 / 22$ & & NR & [38] \\
\hline 17. COVID-19 presenting as a stroke & 4 & 81 & CVA= 4/4 (Ischaemic Stroke: $4 / 4)$ & & $75 \%$ & [39] \\
\hline $\begin{array}{l}\text { 18. COVID-19 presenting with ophthalmoparesis from cranial } \\
\text { nerve palsy }\end{array}$ & 2 & $\begin{array}{l}36 \\
71\end{array}$ & $\begin{array}{l}\text { Cranial Nerve Palsy }=2 / 2 \\
\text { (Oculomotor-1/2; Abducens-1/2) }\end{array}$ & & $0 \%$ & [40] \\
\hline $\begin{array}{l}\text { 19. Status of SARS-CoV-2 in cerebrospinal fluid of patients } \\
\text { with COVID-19 and stroke }\end{array}$ & 2 & $\begin{array}{l}31 \\
62\end{array}$ & $\begin{array}{l}\mathbf{S A H}=1 / 1 \\
\mathbf{C V A}=1 / 1 \text { (Ischaemic Stroke: } 1 / 1) .\end{array}$ & & $0 \%$ & [41] \\
\hline $\begin{array}{l}\text { 20. Emergency room neurology in times of COVID-19: } \\
\text { malignant ischaemic stroke and SARS-CoV-2 infection }\end{array}$ & 1 & 36 & CVA= $1 / 1$ (Ischaemic Stroke: $1 / 1)$ & & $100 \%$ & [42] \\
\hline $\begin{array}{l}\text { 21. Large-Vessel Stroke as a Presenting Feature of COVID-19 } \\
\text { in the Young }\end{array}$ & 5 & 40.4 & CVA $=5 / 5$ (Ischaemic Stroke:5/5) & & $0 \%$ & [43] \\
\hline 22. Guillain-Barré syndrome related to COVID-19 infection & 1 & 71 & Guillain-Barré Syndrome= 1/1 & & $100 \%$ & [44] \\
\hline 23. Features of anosmia in COVID-19 & 114 & 47 & Anosmia $=54 / 114$ & & $4 \%$ & [45] \\
\hline 24. Neurologic Features in in Severe SARS-CoV-2 Infection & 58 & 63 & $\begin{array}{l}\text { Corticospinal Tract signs }=39 / 58 \\
\text { (Dysexecutive Syndromes-14/39). } \\
\text { CVA }=3 / 58 \text { (Ischaemic Stroke:3/58). }\end{array}$ & $\begin{array}{l}\text { Agitation= 40/58 (Confusion: } \\
26 / 40)\end{array}$ & $0 \%$ & [46] \\
\hline $\begin{array}{l}\text { 25. A first case of meningitis/encephalitis associated with } \\
\text { SARS-Corona-Virus-2 }\end{array}$ & 1 & 24 & Meningitis/Encephalitis $=1 / 1$ & & $0 \%$ & [47] \\
\hline $\begin{array}{l}\text { 26. Coagulopathy and Antiphospholipid Antibodies in } \\
\text { Patients with Covid-19 }\end{array}$ & 1 & 69 & Multiple cerebral infarctions $=1 / 1$ & & $0 \%$ & [48] \\
\hline $\begin{array}{l}\text { 27. Neurological Complications of Coronavirus Disease } \\
\text { (COVID-19): Encephalopathy }\end{array}$ & 1 & 74 & Encephalopathy=1/1. & $\mathbf{A M S}=1 / 1$ & $\begin{array}{l}\text { Poor } \\
\text { Prognosis }\end{array}$ & [49] \\
\hline $\begin{array}{l}\text { 28. Neurologic Manifestations of Hospitalized Patients with } \\
\text { Coronavirus Disease } 2019 \text { in Wuhan, China }\end{array}$ & 214 & 52.7 & $\begin{array}{l}\text { Neurological symptoms }=78 / 214 \\
\text { Dizziness }=36 / 214 \\
\text { CVA= }=6 / 214 \text { (Ischaemic Stroke:5/6; } \\
\text { ICH:1/6) } \\
\text { Ataxia= } 1 / 214 \\
\text { Seizure }=1 / 214 \\
\text { Taste disturbances= } 12 / 214 \\
\text { Anosmia }=11 / 214 \\
\text { Visual disturbances= }=3 / 214 \\
\text { Neuropathy }=5 / 214\end{array}$ & $\begin{array}{l}\text { AMS }=16 / 214 \\
\text { Headache }=28 / 214\end{array}$ & NR & [50] \\
\hline
\end{tabular}




\begin{tabular}{|c|c|c|c|c|c|c|}
\hline 29. Encephalitis as a clinical manifestation of COVID-19 & 1 & NR & Encephalitis= 1/1. & & $0 \%$ & [51] \\
\hline $\begin{array}{l}\text { 30. COVID-19-associated Acute Hemorrhagic Necrotizing } \\
\text { Encephalopathy: CT and MRI Features }\end{array}$ & 1 & NR & Acute Necrotizing Encephalopathy= 1/1. & & $0 \%$ & [19] \\
\hline $\begin{array}{l}\text { 31. Guillain-Barré Syndrome associated with SARS-CoV-2 } \\
\text { infection: causality or co-incidence? }\end{array}$ & 1 & 61 & Guillain-Barré Syndrome= 1/1 & & $0 \%$ & [52] \\
\hline $\begin{array}{l}\text { 32. Delirium is a presenting symptom of COVID-19 in frail, } \\
\text { older adults: a cohort }\end{array}$ & $\begin{array}{l}\text { HC: } \\
210 \\
\text { CC: } \\
238\end{array}$ & $\begin{array}{l}\text { HC: } \\
77.9 \\
\text { CC: } \\
73.0\end{array}$ & & $\begin{array}{l}\text { Delirium } \\
\text { (HC:53/210; } \\
\text { CC: } 84 / 238)\end{array}$ & NR & [53] \\
\hline $\begin{array}{l}\text { 33. Continuous Electroencephalography (cEEG) } \\
\text { Characteristics and Acute Symptomatic Seizures in } \\
\text { COVID-19 Patients }\end{array}$ & 22 & 66.5 & $\begin{array}{l}\text { Seizure-like episode }=5 / 22 \\
\text { Seizure }=2 / 22\end{array}$ & AMS $=17 / 22$ & $27 \%$ & [54] \\
\hline $\begin{array}{l}\text { 34. Risk of Ischemic Stroke in Patients with Covid-19 versus } \\
\text { Patients with Influenza }\end{array}$ & 2132 & 69 & CVA $=31 / 2132$ (Ischaemic Stroke: 31/2132) & & NR & [55] \\
\hline 35. Acute myelitis after SARS-CoV-2 infection: A case Report & 1 & 66 & Post-infectious acute myelitis $=1 / 1$ & & $0 \%$ & [56] \\
\hline $\begin{array}{l}\text { 36. Two patients with acute meningo-encephalitis } \\
\text { concomitant to SARS-CoV-2 infection }\end{array}$ & 2 & 65.5 & Meningitis/Encephalitis $=2 / 2$ & & $0 \%$ & [57] \\
\hline $\begin{array}{l}\text { 37. Clinical Characteristics and outcomes of inpatients with } \\
\text { neurological disease and COVID-19 }\end{array}$ & 43 & 76.9 & $\begin{array}{l}\text { CVA=43/43 (Ischaemic Stroke:35/43; } \\
\text { ICH:3/43; TIA:5/43) }\end{array}$ & & $15 \%$ & [58] \\
\hline $\begin{array}{l}\text { 38. Acute cerebrovascular disease following COVID-19: a } \\
\text { single center, retrospective, observational study }\end{array}$ & 221 & NR & $\begin{array}{l}\text { CVA=13/221 (Ischaemic Stroke:11/221; } \\
\text { ICH:1/221; CVST:1/221) }\end{array}$ & & $2.3 \%$ & [13] \\
\hline $\begin{array}{l}\text { 39. Cerebrospinal Fluid Features in Patients with Coronavirus } \\
\text { Disease } 2019 \text { and Neurological Manifestations: } \\
\text { Correlation with Brain Magnetic Resonance Imaging } \\
\text { Findings in } 58 \text { Patients }\end{array}$ & 58 & 62 & Encephalopathy $=47 / 58$ & Seizures $=6 / 58 ;$ Headaches $=3 / 58$ & $0 \%$ & [59] \\
\hline
\end{tabular}

AMS: Altered Mental Status; APR: Awaiting Peer Review (unpublished data); CC: Community Cohort; CNS: Central Nervous System; CVA: Cerebrovascular Accident; CVST: Cerebral Venous Sinus Thrombosis; HC: Hospital Cohort; ICH: Intracranial Hemorrhage; NR: Not Reported; P/M: Post-Mortem; SAH: Sub-Arachnoid Hemorrhage; TIA-Transient Ischemic Attack

[7,8]. Patients experience headaches, nausea and vomiting suggesting the coronavirus affect other physiological systems as well $[9,10]$. Several studies have investigated how SARS-CoV-2 penetrates the central nervous system (CNS). Pre-clinical studies in rodents point to intranasal spread and dissemination of coronaviruses through the cribriform plate to the olfactory bulbs with relay to the thalamus and the brainstem $[11,12]$. Infection via the olfactory bulb is consistent with COVID-19 infected patients who experience loss of smell and taste sensation [13]. A large study consisting of 10069 participants in Iran reported that $83.38 \%$ of infected individuals experienced both anosmia and a reduction in their taste sensation [14]. Another possible route involves peripheral nerves being infected and then propagating the virus via trans-synaptic transfer to the CNS [15]. Haematogenous and lymphatic spread seems less likely $[13,16,17]$. Conversely, a study by Baig et al. [18] proposes that viremia in the brain may be initiated by peripheral circulation or via the transcribrial route. It is therefore possible that haematogenous spread could introduce the viral pathogen into the CNS and disperse viral constituents into the slow-moving cerebral blood. Once in the CNS, SARS CoV-2 interacts with Angiotensin Converting Enzyme-2 (ACE-2) receptors to traverse the capillary endothelium and instigate a cascade of haemorrhagic events [18]. A study by Poyiadji et al. [19] reported a case of acute haemorrhagic necrotizing encephalopathy in a COVID-19 patient. It is known that this condition has been associated with cytokine storms [20], and such cytokine storms have recently been reported in severe cases of COVID-19 [21,22]. These cytokine storms and associated sequelae may be the downstream effect of activated Toll-like receptors. Studies have highlighted the neurovirulence of SARS CoV-2, however its exact mechanism of CNS invasion remains to be fully elucidated. The efficacy and integrity of the blood brain barrier in COVID-19 patients has also not been established as yet.

\section{Neuropathological effects in COVID-19-infected individuals}

\section{Direct effects on brain function}

SARS CoV-2 has been detected by genomic sequencing in cerebrospinal fluid confirming its presence in the brain [60]. Digital droplet PCR, viral outgrowth assay, and single-cell RNA sequencing of brain samples from SARS2 patients along with multi-labelled immunohistochemical analysis may assist in establishing the neurotropism of SARS-CoV-2 [61]. The presence of certain nonspecific symptoms further suggests that COVID-19 may involve multiple brain regions (Figure 1). Notably in previous outbreaks, traces of viral antigens have been discovered in the nucleus of the solitary tract and the nucleus ambiguous. These nuclei are responsible for autonomic innervation to smooth muscle, blood vessels and glands of the respiratory airways. Damaging effects of the virus in these regions of the brainstem, particularly the cardiorespiratory centre, can therefore precipitate detrimental consequences to an infected individual.

There seems to be a good correlation between disease severity and the degree of neurological symptoms. For instance a cohort of COVID-19 patients studied by Mao et al. [50] revealed greater neurological pathology with increased severity of COVID-19 infection, displaying acute cerebrovascular events and altered levels of consciousness. It is now known that in some critically ill patients, increased levels of $\mathrm{D}$-dimer and diminishing platelets predispose them to developing a cerebrovascular accident $[62,63]$, while in others with underlying hypertension, an increased risk of intracranial haemorrhage have been documented. These findings have further been supported by autopsies of COVID-19 patients showing tissue oedema and evidence of neurodegeneration [64], as well as reports of the occurrence of seizures resulting from inadequate brain perfusion [47]. It is therefore likely that patients with COVID-19 may experience respiratory failure associated with severe hypoxia and subsequent cerebral damage if the hypoxia remains untreated [65]. Most recently delirium and hallucinations have been reported as common clinical manifestations of the resultant hypoxic damage.

A case study that documented the clinical course of a patient with neurologic manifestations that included encephalopathy with aphasia, also reported the patient to have multiple other comorbidities (atrial fibrillation, cardioembolic stroke, cellulitis, Parkinson's disease, Chronic obstructive pulmonary disorder) [49]. A CT brain scan revealed no significant new findings but his EEG showed changes 


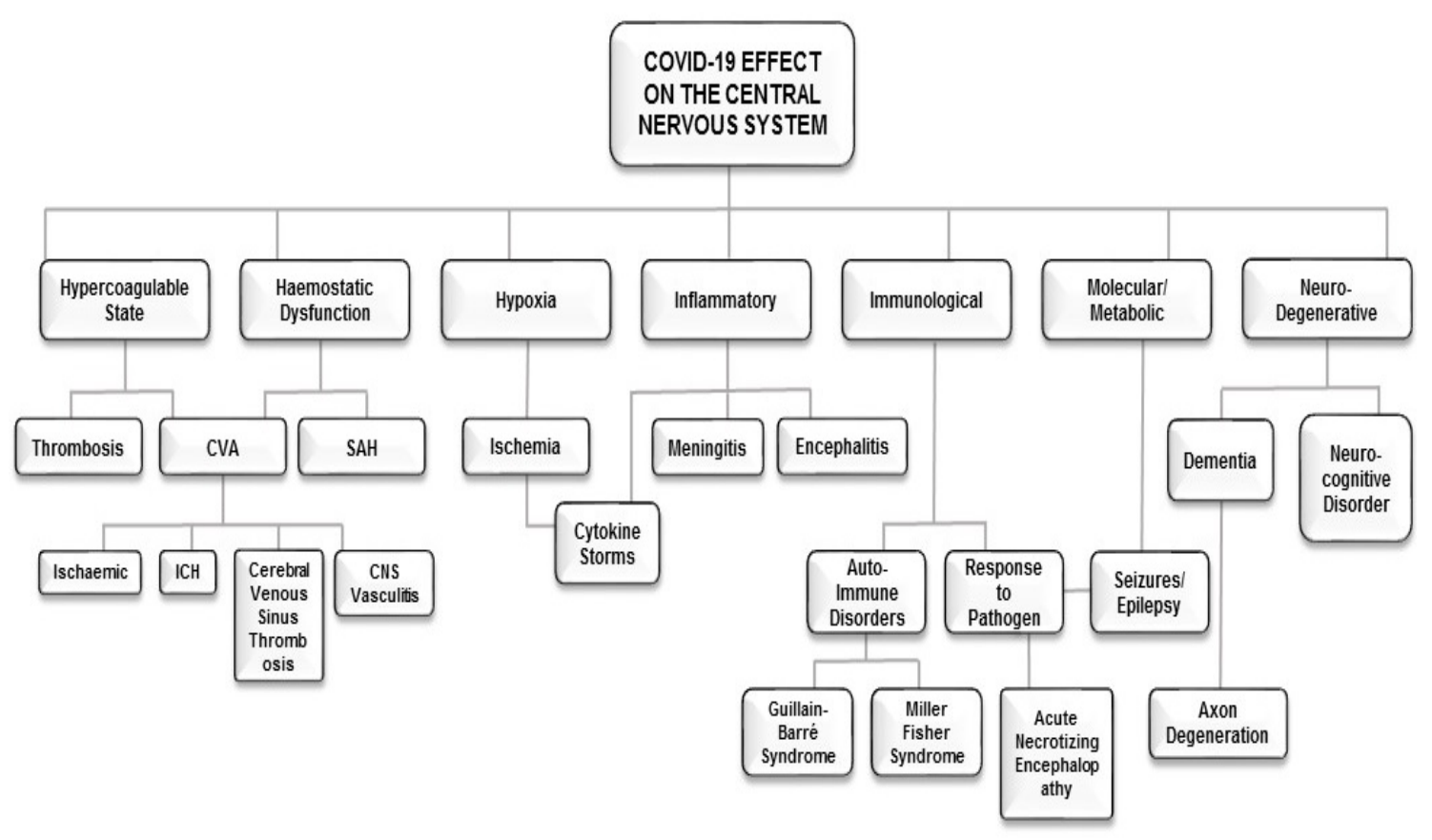

Figure 1. The clinical manifestations of COVID-19 on the CNS with its proposed mechanisms of action. CVA: Cerebrovascular Accident; CNS: Central Nervous System; ICH: Intracranial Hemorrhage; SAH: Sub-Arachnoid Hemorrhage

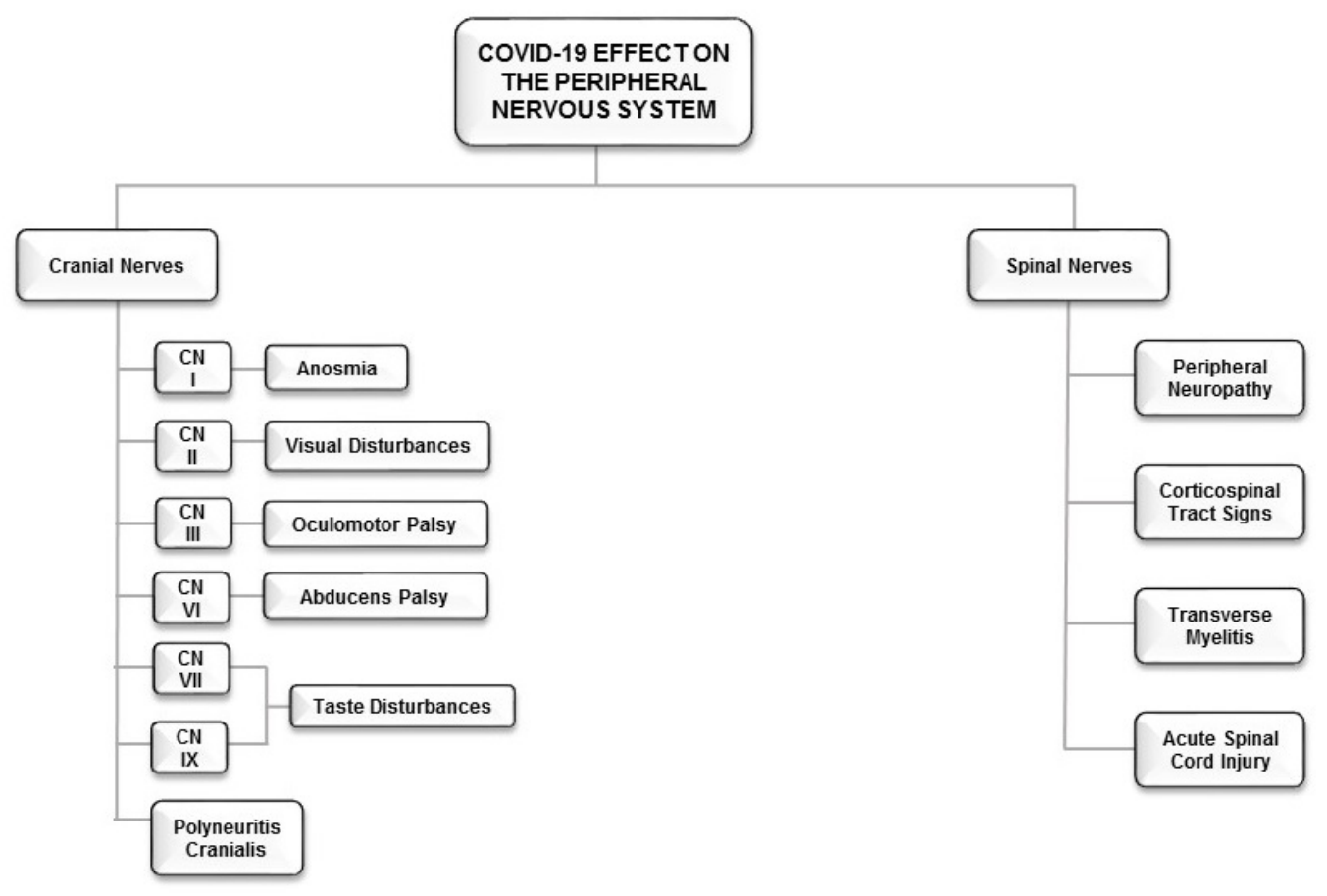

Figure 2. The clinical manifestations of COVID-19 on the Peripheral Nervous System.

consistent with temporal lobe dysfunction [49]. Since COVID-19 may produce a wide range of acute neurological deficits ranging from milder symptoms such as headaches, nausea, vomiting, anosmia and neuropathy to more insidious complications such as cerebrovascular incidents, seizures, viral and autoimmune encephalitis, the neurological impact of COVID-19 appears to be varied and patient-specific (Figure 1). This view is supported by the findings of a recent UK-based study reporting COVID-19 patients to present with a variety of neurological and psychiatric disorders including ischemic strokes, intracerebral haemorrhage, encephalopathy, psychosis and affective disorder [23]. The ramifications of COVID-19 therefore caution against generalized symptomology and points to the development of precision-targeted and individualized diagnostics and neurotherapeutics. Furthermore, the effects of SARS-CoV-2 should not be limited to the brain as pathologies related to the peripheral nervous system have also been reported (Table 1, Figure 2). 


\section{Indirect effects on brain function}

Currently the treatment of patients suffering from COVID-19 is symptomatically based. In addition to managing the disease medically, patients also face isolation and lose direct human interaction with their non-infected family members. Human beings are innately gregarious and have evolved to develop complex social hierarchies. With the number of restrictions that social isolation and limited interaction institutes, infected patients may be experiencing a multitude of emotions. These may range from loneliness, apathy, despondence, despair, anxiety, depression, uncertainty and anguish [66]. Social isolation further potentiates stress and anxiety and these emotions are known to negatively impact the neuroendocrine system [67]. Chronically elevated levels of cortisol, stemming from severe mental distress, can potentiate pseudo-symptoms (including fever, cough, and hypoxia) even in uninfected individuals [60].

A key factor influencing how people respond and their ability to cope with stressful events (in this particular case a global pandemic) is based on their perceptions of the condition [68]. Since January 2020, numerous guidelines have been published by the National Health Commission of China related to providing psychological crisis interventions for COVID-19 [69]. Williams [70] highlighted that two prominent studies involved vulnerable populations: the elderly and international migrant workers $[71,72]$. It was reported that during the epidemic in China, there was a significant escalation in the number of psychological presentations relating to depression, anxiety and stress [73]. A large electronic health record study involving approximately 60000 participants revealed that new onset dementia was 2-3 times more common in patients following hospitalization for COVID-19 in comparison to hospitalization for other medical events [74]. Clear communication has been shown to be critical under these circumstances. Sharing management plans with patients and their families have also been shown to be crucial for the wellbeing of the infected individuals. Decreasing the feeling of isolation for affected COVID-19 patients can be achieved through the use of safe social platforms (social messaging/ video calling applications). With multiple major disasters, the Chinese government had made significant strides in improving the mental health service system. During COVID-19, a new model (West China Hospital) involving the internet was developed. This model involved providing online therapy and support to patients, their families and healthcare workers (HCWs) from psychiatrists, psychologists, and social workers. Experience with this model further demonstrates the importance of having a comprehensive approach to the treatment of COVID-19 with due consideration for the risk of adverse effects elicited by elements of the treatment (for example self-isolation).

\section{Neuropsychological effects in COVID-19-infected individuals}

Public stigma with its influence on the psychological wellbeing of an individual, has arisen as another major factor that patients with COVID-19 may face (COVID-2019 situation reports). Following recovery from COVID-19, patients may still encounter social prejudice and stigmatization as reported in a study by Gammon et al. [75] that explored stigmatization in Methicillin-Resistant Staphylococcus Aureus (MRSA) carriers. A similar observation was made during the Middle East respiratory syndrome (MERS) coronavirus outbreak when families and patients faced social stigma and discrimination even after being virus-free [76,77]. These findings suggest that continued support and regular therapy is needed to assist the patient with the psychological after-math of COVID-19, especially in view of the potential long-term effects of stigmatization and social prejudice on mental wellbeing.

\section{COVID-19 Effects in Uninfected Individuals}

A few studies have shown that negative emotions are not only associated with infected patients. Even amongst healthy individuals who had been quarantined, feelings of anger and anxiety have been expressed. These symptoms may not necessarily be present immediately but may only surface 4-6 months after the quarantine period had been lifted. Feelings of insecurity and the unpredictability related to the COVID-19 situation are believed to be potent contributors to stress [78-80].

South Korea, being one of the most affected countries by COVID-19, recognized the need for mental health care during this global crisis. As such mental health care services and experts have been deployed across South Korea and information pamphlets have been created and distributed widely [81]. The information on the pamphlet reported that if an individual is experiencing anxiety, anger, somatic symptoms, decreased energy states, concentration problems, rumination, changes to sleep patterns and mood, they should seek evaluation by a mental healthcare professional [81]. This strategy of availing accurate information and services to the broader public has been acknowledged as one of the reasons why the South Korean battle against COVID-19 has been so successful (Korean Center for Disease Control press release 31 March 2020).

The stressors that may accompany quarantine have been identified as the fear of acquiring the infection, frustration and boredom, having insufficient supplies and unreliable sources of information [82]. These observations point to a correlation between quarantine of a longer duration and poor mental health [82], especially in view of the diagnosis of post-traumatic stress, anger and avoidance behaviours in some previously quarantined individuals $[82,83]$. For instance it was noted that quarantine periods of longer than 10 days augmented posttraumatic stress in comparison to that of a shorter duration [84]. This poses a great concern for many countries as they have either initiated lockdowns or encouraged quarantines for several days/weeks. While it may be thought that voluntary quarantine may lessen the negative impact on mental health in comparison to mandatory quarantine, there is not enough evidence to fully support this.

To attempt to reduce viral transmission, varying phases of lockdown measures have been implemented all throughout the United States of America (USA), Europe, Asia and Africa [85]. These have been accompanied by appropriate information campaigns implemented from their respective governments. USA had been the most affected and had the highest mortality rates by the pandemic despite their public health efforts. Within Europe, countries have opted for consistently monitoring, increasing or relieving restrictions depending on the state of the pandemic at the specific point in time. Africa has elected for a lower lockdown level since the start of the year. Higherincome countries, like Australia and New Zealand received praise for their COVID-19 responses and in their swift actions. There is hope that public health measures particularly mass COVID-19 vaccination programmes will assist in reducing transmission dynamics. Most countries in Asia and Africa have been subjected to a slow vaccine rollout, thus contributing to the mortality rates.

\section{Neuropathological Changes in Uninfected Individuals}

Chronic stress levels cause an overstimulation of the hypothalamicpituitary axis (HPA), subsequently stimulating the release of glucocorticoids, catecholamines, vasopressin and simultaneously the sympathetic "fight or flight" system. Loneliness activates a similar 
pathway as indicated by Segrin et al. [86]. Overstimulation of the HPA system can result in adjusted concentrations of neurotransmitters, induction of oxidative stress and changes in inflammatory processes [67]. Persistent stress leads to activation of the amygdala and other primitive limbic structures, contributing to fear retention [87]. Centuries ago, these biological structures would predominate to allow primitive humans to face severe life-threatening situations. However, over the years, these structures have become more dormant while the human brain evolved to develop a larger cerebral cortex to provide higher levels of cognition (like rational judgement and reasoning). This supposition is supported by subcortical structures such as the periaqueductal gray matter and the amygdala becoming more active in PTSD patients when a life-threatening stimulus is perceived [87]. This may account for a decrease in rational thinking and an upsurge in fear-driven behaviours. Promising solutions aimed at improving the neuropsychological status and mental health of individuals will be discussed later in this review.

\section{Strategies against COVID-19}

\section{Learning from previous experiences}

While it is difficult to anticipate the long term implications that COVID-19 will have on physical and mental health, it can be expected to elicit neuropsychiatric changes similar to those previously shown by influenza, SARS and the MERS. A diverse array of behavioural modifications inclusive of anxiety, panic attacks, depression, psychotic symptoms and even suicide have been reported particularly during the early phase of the SARS outbreaks [3,60]. During and after the SARS coronavirus outbreak in 2003, more cases of PTSD, anxiety, depression, and fear were reported among HCWs [88].

A study evaluating the psychological impact of quarantine during the MERS outbreak had higher scores when assessed using the hospital anxiety and depression scale $[76,89]$. These findings are comparable to the psychological distress experienced by individuals in Nigeria during the Ebola crisis $[76,90]$. In 2015, the MERS infection in Korea resulted in 186 cases of infection, 38 deaths and 16,692 exposed and quarantined individuals. Since this outbreak, PTSD symptoms had increased amongst the HCWs who cared for the MERS-infected and hemodialysis patients in quarantine [81]. The stress and anxiety experienced by the HCWs were related to errors, missing of diagnoses and delays due to communication failure, amongst others. Therefore, recognizing such trigger events in the work environment of HCWs during an outbreak should be part of hospital management guidelines governing its workforce. Learning from these past outbreak experiences and fine-tuning solutions could assist extensively during the current COVID-19 pandemic.

\section{Coping mechanisms}

\section{Online Counselling Services}

Park and Park [81] highlighted that adopting measures like relying on trustworthy sources of information, communicating with loved ones, expressing negative emotions, scheduling enjoyable activities and maintaining activities of daily living, are valuable in trying to mitigate the effects of being quarantined. For government and policy makers, this information should be disseminated widely to the population. Additionally, information regarding the mental health status and their levels of distress among COVID-19 patients and the HCWs who provide care for them, should be documented. Xiang et al. [60] suggested a 3-tiered approach to mediating the effects of COVID-19 that can be applied to all affected countries. The first tier entails the need for a multidisciplinary team of psychiatrists, psychologists and other clinical mental healthcare professionals. The second tier involves the provision of factually correct, reliable updates about COVID-19 on a regular basis. The third tier pertains to the delivery of necessary psychological therapy via various platforms including online sessions or applications $[60,81]$.

Upon the COVID-19 outbreak in China, the Second Xiangya Hospital was quick in their response in tackling the psychological demands of staff. Their response plan incorporated 3 components: (i) assembling a team of medical personnel, (ii) online courses with a hotline and (iii) stress-relieving activities aimed at providing assistance to staff facing psychological difficulties [91]. While such a system appears advantageous in providing support to staff members, some of the medical staff were reluctant to make use of these services as they were in denial about admitting they were having any issues. The hospital then sought to identify key problems experienced by the staff members. Upon interviewing 13 members of staff, they stated that they were concerned about spreading the SARS COV-2 virus to their families, diminishing supplies of protective equipment, dealing with uncooperative patients and the feeling of helplessness when caring for terminal patients [91]. The hospital provided multiple solutions to meet the needs of their staff. These included arranging temporary places of rest for the staff away from their family members, and hospital staff would assist with those patients that were not compliant to quarantine regulations. Staff were provided with adequate training to enable them to feel competent when attending to critically ill patients. Furthermore, the hospital ensured that personal protective gear would be appropriately allocated, and the staff were taught to manage their stress through relaxing activities. This study highlighted the effectiveness of providing the correct resources when managing pandemics of the nature of COVID-19. This is a lesson that most countries could follow.

With the progression in smartphones and their communication applications, countries should exploit these technological advances to provide the large-scale psychological aid that is needed. This concept was successfully utilized in several provinces in China during the COVID-19 outbreak using Questionnaire Star, an online survey programme. A multicentre survey was conducted in China comprising of 1563 participants. The survey results showed that $73.4 \%$ of the participants experienced stress-related symptoms, 50.7\% experienced depression, $44.7 \%$ experienced anxiety, and insomnia was reported in $36.1 \%$ of participants. Such surveys are imperative in determining what psychological consequences are most prevalent, the type of mental health resources needed and how they will be distributed. Liu et al. [92] has indicated that there are numerous free sources of published documentation which can be used as the framework to base mental health strategies on. China was also able to employ free 24-hour online counselling services, primarily using WeChat-based resources throughout its 31 states [92]. Self-help options included cognitive behavioural therapy and even programmes with artificial intelligence were also made available [93]. Such programmes were also beneficial in suicide prevention. The scope for trying new platforms and introducing telemedicine, specifically telepsychological counselling, is growing [76].

\section{Cognitive Behavioural Therapy}

Cognitive behavioural therapy (CBT) helps people by learning techniques to identify and modify negative thoughts and behaviours. Naeem et al. [94] has proposed the application of CBT during this 
global pandemic. The therapist would encourage rationalization of the situation, in addition to focusing on the individual's lifestyle, level of physical activity, stress management and sleep patterns. There has been evidence to suggest that even online CBT can generate a positive impact and promote resilience [94]. With benefits such as wide-spread delivery and being cost-effective, CBT also has the potential to be adapted to address individual patient circumstances comparable to precision-based medicine.

\section{Mental Health First Aid}

Early detection of mental health problems, improving mental health literacy and providing affordable, accessible treatment should be a global health priority [95]. Previous studies have demonstrated that members of the general population experience difficulty in identifying the disorder when presented with a hypothetical situation or vignette of a person with a mental disorder. A lack of literacy forms a barrier in the identification, management and prevention of mental disorders whilst concurrently contributes to stigma often associated with mental health conditions.

A mental health problem can be defined as a significant and persistent alteration to a person's thoughts or behaviours that is disruptive to their daily activities. Mental health first aid (MHFA) aims to identify the detrimental patterns of behaviour and assist the person by providing them with the appropriate support. MHFA incorporates five steps compressed to form the acronym "ALGEE." The five key steps include: (1) approach the person, assess their situation and assist accordingly, (2) listen without judgement, (3) give information, support and advice, (4) encourage help-seeking from a relevant healthcare professional and (5) encourage additional support modalities [96]. Mental health first aid have been established through Delphi methodology [97-99]. The conventional mental health first aid course is taught by an instructor to groups of participants but has the potential to be modified to diverse settings, cultural and age groups $[100,101]$. More recently, it has been adapted to an electronic learning (eLearning) platform which would be favourable during this pandemic. The benefit of eLearning is that it is widely accessible and may be more cost-effective, by eliminating the need for an instructor while being as effective as the standard mental health first aid training course [102]. MHFA courses are available in over 20 countries (including the US, Pakistan, Sweden) and can be translated into different languages.

Another notable strategy following the influenza outbreaks, was the establishment of a resilience training program to facilitate the preparation for future crises by learning from previous viral outbreaks [103]. Psychological first aid (PFA) could be a valuable tool in providing continual support and assist in alleviating stress [104-106]. Johns Hopkin's PFA framework comprises of the acronym "RAPID" where each letter is representative of one of five steps. The first being establishing a rapport and practicing reflective listening when interacting with a person seeking help. The second step entails assessing the patient's mental state and establish what their needs are. The third step involves prioritizing the most severe cases and the fourth step involves providing the relevant level of care for them. The fifth and final step is disposition and follow-up through consistent monitoring. The RAPID-PFA may be beneficial in the context of the COVID-19 pandemic, however its appropriateness remains to be evaluated $[76,106]$. Training HCWs in MHFA or PFA would empower them with the necessary skills to enable them to identify and manage mental health problems to mitigate the current and future effects of COVID-19.

\section{Mobile Outreach Programmes}

Mobile outreach programmes could be devised to assist those vulnerable populations and those who do not have access to online platforms [91]. Mental healthcare professionals could conduct these mobile outreach programmes using designated medically equipped vehicles. Regular outreach programmes especially after the COVID-19 pandemic should be part of reintegration and intervention plans. With an abundance of approaches directed towards mental health problems during a crisis like COVID-19, implementation and evaluation of one or more feasible options may have the most pronounced positive impact.

\section{Conclusion}

While several scientists and clinicians around the world are grappling with the containment and management of the SARS COV-2 virus, it has overwhelmed many healthcare systems and has severely disrupted the way human beings have been living. The impact of the virus and subsequent pandemic on the mental wellbeing of people continues to be less prominent in discussions by HCWs and health care authorities, despite a call for the onset of mental healthcare to be immediate [60]. Regular clinical screening for symptoms of depression, stress, anxiety and suicidal behaviours among HCWs and COVID-19 infected patients should be conducted [60], especially in view of psychotherapeutic interventions being proven to be beneficial to those individuals exhibiting severe signs of stress $[3,4]$. Despite limitations such as cognitive dissonance, it appears that implementation of online platforms during times of crisis like COVID-19 could bring some relief and improve mental wellbeing. It is known that mental health challenges are the result of a complex intermingling of relationships that exist between biological, environmental, psychosocial factors, which in the present pandemic, should be accounted for.

\section{Funding}

This research did not receive any specific grant from funding agencies in the public, commercial or not-for-profit sectors.

\section{References}

1. World Health Organization, 2020. Novel Coronavirus - China. [online] Available at https://wwwwhoint/csr/don/12-january-2020-novel-coronavirus-china/en/ [Accessed 17 February 2020].

2. Shah K, Kamrai D, Mekala H, Mann B, Desai K, et al. (2020) Focus on Mental Health During the Coronavirus (COVID-19) Pandemic: Applying Learnings from the Past Outbreaks. Cureus 12: e7405. [Crossref]

3. Maunder R, Hunter J, Vincent L, Bennett J, Peladeau N, et al. (2003) The immediate psychological and occupational impact of the 2003 SARS outbreak in a teaching hospital. CMAJ 168: 1245-1251. [Crossref]

4. Folkman S, Greer S (2000) Promoting psychological well-being in the face of serious illness: when theory, research and practice inform each other. Psychooncology 9: 11-9. [Crossref]

5. Wang C, Pan R, Wan X, Tan Y, Xu L, et al. (2020) Immediate Psychologica Responses and Associated Factors during the Initial Stage of the 2019 Coronavirus Disease (COVID-19) Epidemic among the General Population in China. Int J Environ Res Public Health 17: 1729. [Crossref]

6. Perret JL, Best CO, Coe JB, Greer AL, Khosa DK, et al. (2020) Prevalence of mental health outcomes among Canadian veterinarians. J Am Vet Med Assoc 256: 365-375. [Crossref]

7. Helbok R, Chou SH, Beghi E, Mainali S, Frontera J, et al. (2020) GCS-NeuroCOVID consortium; EAN COVID task force. NeuroCOVID: it's time to join forces globally. Lancet Neurol 19: 805-806. [Crossref]

8. Lou JJ, Movassaghi M, Gordy D, Olson MG, Zhang T, et al. (2021) Neuropathology of COVID-19 (neuro-COVID): clinicopathological update. Free Neuropathol 2: 2. [Crossref] 
9. Li Y, Li M, Wang M, Zhou Y, Chang J, et al. (2020) Acute cerebrovascular disease following COVID-19: a single center, retrospective, observational study. Stroke Vasc Neurol 5: 279-284. [Crossref]

10. Asadi-Pooya AA, Simani L (2020) Central nervous system manifestations of COVID-19: A systematic review. J Neurol Sci 413: 116832. [Crossref]

11. Netland J, Meyerholz DK, Moore S, Cassell M, Perlman S (2008) Severe acute respiratory syndrome coronavirus infection causes neuronal death in the absence of encephalitis in mice transgenic for human ACE2. J Virol 82: 7264-7275. [Crossref]

12. Li F (2016) Structure, Function, and Evolution of Coronavirus Spike Proteins. Annu Rev Virol 3: 237-261. [Crossref]

13. Li YC, Bai WZ, Hashikawa T (2020) The neuroinvasive potential of SARS-CoV2 may play a role in the respiratory failure of COVID-19 patients. J Med Virol 92: 552-555. [Crossref]

14. Bagheri SH, Asghari A, Farhadi M, Shamshiri AR, Kabir A, et al. (2020) Coincidence of COVID-19 epidemic and olfactory dysfunction outbreak in Iran. Med J Islam Repub Iran 34: 62. [Crossref]

15. Matsuda K, Park CH, Sunden Y, Kimura T, Ochiai K, et al. (2004) The vagus nerve is one route of transneural invasion for intranasally inoculated influenza a virus in mice. Vet Pathol 41: 101-107. [Crossref]

16. Ding Y, He L, Zhang Q, Huang Z, Che X, et al. (2004) Organ distribution of severe acute respiratory syndrome (SARS) associated coronavirus (SARS-CoV) in SARS patients: implications for pathogenesis and virus transmission pathways. J Pathol 203 622-630. [Crossref]

17. Xu J, Zhong S, Liu J, Li L, Li Y, et al. (2005) Detection of severe acute respiratory syndrome coronavirus in the brain: potential role of the chemokine mig in pathogenesis. Clin Infect Dis 41: 1089-1096. [Crossref]

18. Baig AM (2020) Neurological manifestations in COVID-19 caused by SARS-CoV-2. CNS Neurosci Ther 26: 499-501. [Crossref]

19. Poyiadji N, Shahin G, Noujaim D, Stone M, Patel S, et al. (2020) COVID-19-associated Acute Hemorrhagic Necrotizing Encephalopathy: Imaging Features. Radiology 296: E119-E120. [Crossref]

20. Rossi A (2008) Imaging of acute disseminated encephalomyelitis. Neuroimaging Clin $N A m$ 18: 149-161, ix. [Crossref]

21. Mehta V, Goel S, Kabarriti R, Cole D, Goldfinger M, et al. (2020) Case Fatality Rate of Cancer Patients with COVID-19 in a New York Hospital System. Cancer Discov 10: 935-941. [Crossref]

22. Chen R, Chen J, Meng QT (2020) Chest computed tomography images of early coronavirus disease (COVID-19). Can J Anaesth 67: 754-755. [Crossref]

23. Varatharaj A, Thomas N, Ellul MA, Davies NWS, Pollak TA, et al. (2020) CoroNerve Study Group. Neurological and neuropsychiatric complications of COVID-19 in 153 patients: a UK-wide surveillance study. Lancet Psychiatry 7: 875-882. [Crossref]

24. Coolen T, Lolli V, Sadeghi N, Rovai A, Trotta N, et al. (2020) Early postmortem brain MRI findings in COVID-19 non-survivors. Neurology 95: e2016-e2027. [Crossref]

25. Webb S, Wallace VC, Martin-Lopez D, Yogarajah M (2020) Guillain-Barré syndrome following COVID-19: a newly emerging post-infectious complication. BMJ Case Rep 13: e236182. [Crossref]

26. Kremer S, Lersy F, de Sèze J, Ferré JC, Maamar A, et al. (2020) Brain MRI Findings in Severe COVID-19: A Retrospective Observational Study. Radiology 297: E242-E251. [Crossref]

27. Solomon IH, Normandin E, Bhattacharyya S, Mukerji SS, Keller K, et al. (2020) Neuropathological Features of Covid-19. N Engl J Med 383: 989-992. [Crossref]

28. Dalakas MC (2020) Guillain-Barré syndrome: The first documented COVID-19triggered autoimmune neurologic disease: More to come with myositis in the offing. Neurol Neuroimmunol Neuroinflamm 7: e781. [Crossref]

29. von Weyhern CH, Kaufmann I, Neff F, Kremer M (2020) Early evidence of pronounced brain involvement in fatal COVID-19 outcomes. Lancet 395: e109. [Crossref]

30. Fara MG, Stein LK, Skliut M, Morgello S, Fifi JT, et al. (2020) Macrothrombosis and stroke in patients with mild Covid-19 infection. J Thromb Haemost 18: 2031-2033. [Crossref]

31. Hepburn M, Mullaguri N, George P, Hantus S, Punia V, et al. (2021) Acute Symptomatic Seizures in Critically Ill Patients with COVID-19: Is There an Association? Neurocrit Care 34: 139-143. [Crossref]
32. Reichard RR, Kashani KB, Boire NA, Constantopoulos E, Guo Y, et al. (2020) Neuropathology of COVID-19: a spectrum of vascular and acute disseminated encephalomyelitis (ADEM)-like pathology. Acta Neuropathol 140: 1-6. [Crossref]

33. Jain R, Young M, Dogra S, Kennedy H, Nguyen V, et al. (2020) COVID-19 related neuroimaging findings: A signal of thromboembolic complications and a strong prognostic marker of poor patient outcome. J Neurol Sci 414: 116923. [Crossref]

34. Butt I, Sawlani V, Geberhiwot T (2020) Prolonged confusional state as first manifestation of COVID-19. Ann Clin Transl Neurol 7: 1450-1452. [Crossref]

35. Al-Olama M, Rashid A, Garozzo D (2020) COVID-19-associated meningoencephalitis complicated with intracranial hemorrhage: a case report. Acta Neurochir (Wien) 162 1495-1499. [Crossref]

36. Morassi M, Bagatto D, Cobelli M, D'Agostini S, Gigli GL, et al. (2020) Stroke in patients with SARS-CoV-2 infection: case series. J Neurol 267: 2185-2192. [Crossref]

37. Gutiérrez-Ortiz C, Méndez-Guerrero A, Rodrigo-Rey S, San Pedro-Murillo E, Bermejo-Guerrero L, et al. (2020) Miller Fisher syndrome and polyneuritis cranialis in COVID-19. Neurology 95: e601-e605. [Crossref]

38. Galanopoulou AS, Ferastraoaru V, Correa DJ, Cherian K, Duberstein S, et al. (2020) EEG findings in acutely ill patients investigated for SARS-CoV-2/COVID-19: A smal case series preliminary report. Epilepsia Open 5: 314-324. [Crossref]

39. Avula A, Nalleballe K, Narula N, Sapozhnikov S, Dandu V, et al. (2020) COVID-19 presenting as stroke. Brain Behav Immun 87: 115-119. [Crossref]

40. Dinkin M, Gao V, Kahan J, Bobker S, Simonetto M, et al. (2020) Author response: COVID-19 presenting with ophthalmoparesis from cranial nerve palsy. Neurology 95 : 411. [Crossref]

41. Al Saiegh F, Ghosh R, Leibold A, Avery MB, Schmidt RF, et al. (2020) Status of SARS-CoV-2 in cerebrospinal fluid of patients with COVID-19 and stroke. J Neurol Neurosurg Psychiatry 91: 846-848. [Crossref]

42. González-Pinto T, Luna-Rodríguez A, Moreno-Estébanez A, Agirre-Beitia G, Rodríguez-Antigüedad A, et al. (2020) Emergency room neurology in times of COVID-19: malignant ischaemic stroke and SARS-CoV-2 infection. Eur J Neurol 27: e35-e36. [Crossref]

43. Oxley TJ, Mocco J, Majidi S, Kellner CP, Shoirah H, et al. (2020) Large-Vessel Stroke as a Presenting Feature of Covid-19 in the Young. $N$ Engl J Med 382: e60. [Crossref]

44. Alberti P, Beretta S, Piatti M, Karantzoulis A, Piatti ML, et al. (2020) Guillain-Barré syndrome related to COVID-19 infection. Neurol Neuroimmunol Neuroinflamm 7: e741. [Crossref]

45. Klopfenstein T, Kadiane-Oussou NJ, Toko L, Royer PY, Lepiller Q, et al. (2020) Features of anosmia in COVID-19. Med Mal Infect 50: 436-439. [Crossref]

46. Helms J, Kremer S, Merdji H, Clere-Jehl R, Schenck M, et al. (2020) Neurologic Features in Severe SARS-CoV-2 Infection. N Engl J Med 382: 2268-2270. [Crossref]

47. Moriguchi T, Harii N, Goto J, Harada D, Sugawara H, Takamino J, et al. (2020) A first case of meningitis/encephalitis associated with SARS-Coronavirus-2. Int J Infect Dis 94: 55-58. [Crossref]

48. Zhang Y, Xiao M, Zhang S, Xia P, Cao W, et al. (2020) Coagulopathy and Antiphospholipid Antibodies in Patients with Covid-19. N Engl J Med 382: e38. [Crossref]

49. Filatov A, Sharma P, Hindi F, Espinosa PS (2020) Neurological Complications of Coronavirus Disease (COVID-19): Encephalopathy. Cureus 12: e7352. [Crossref]

50. Mao L, Jin H, Wang M, Hu Y, Chen S, et al. (2020) Neurologic Manifestations of Hospitalized Patients With Coronavirus Disease 2019 in Wuhan, China. JAMA Neurol 77: 683-690. [Crossref]

51. Ye M, Ren Y, Lv T (2020) Encephalitis as a clinical manifestation of COVID-19. Brain Behav Immun 88: 945-946. [Crossref]

52. Zhao H, Shen D, Zhou H, Liu J, Chen S (2020) Guillain-Barré syndrome associated with SARS-CoV-2 infection: causality or coincidence? Lancet Neurol 19: 383-384. [Crossref]

53. Zazzara MB, Penfold RS, Roberts AL, Lee KA, Dooley H, et al. (2021) Probable delirium is a presenting symptom of COVID-19 in frail, older adults: a cohort study of 322 hospitalised and 535 community-based older adults. Age Ageing 50: 40-48. [Crossref]

54. Louis S, Dhawan A, Newey C, Nair D, Jehi L, et al. (2020) Continuous electroencephalography characteristics and acute symptomatic seizures in COVID-19 patients. Clin Neurophysiol 131: 2651-2656. [Crossref] 
55. Merkler AE, Parikh NS, Mir S, Gupta A, Kamel H, et al. (2020) Risk of Ischemic Stroke in Patients with Covid-19 versus Patients with Influenza. medRxiv [Preprint]. [Crossref]

56. Zhao K, Huang J, Dai D, Feng Y, Liu L, et al. (2020) Acute myelitis after SARS-CoV-2 infection: a case report. MedRxiv.

57. Bernard-Valnet R, Pizzarotti B, Anichini A, Demars Y, Russo E, et al. (2020) Two patients with acute meningoencephalitis concomitant with SARS-CoV-2 infection. Eur J Neurol 27: e43-e44. [Crossref]

58. Benussi A, Pilotto A, Premi E, Libri I, Giunta M, et al. (2020) Clinical characteristics and outcomes of inpatients with neurologic disease and COVID-19 in Brescia, Lombardy, Italy. Neurology 95: e910-e920. [Crossref]

59. Lersy F, Benotmane I, Helms J, Collange O, Schenck M, et al. (2021) Cerebrospinal Fluid Features in Patients With Coronavirus Disease 2019 and Neurological Manifestations: Correlation with Brain Magnetic Resonance Imaging Findings in 58 Patients. J Infect Dis 223: 600-609. [Crossref]

60. Xiang F, Wang X, He X, Peng Z, Yang B, et al. (2019) Antibody Detection and Dynamic Characteristics in Patients With Coronavirus Disease 2019. Clin Infect Dis 71: 1930-1934. [Crossref]

61. Bodnar B, Patel K, Ho W, Luo JJ, Hu W (2021) Cellular mechanisms underlying neurological/neuropsychiatric manifestations of COVID-19. J Med Virol 93: 19831998. [Crossref]

62. Wang C, Xie J, Zhao L, Fei X, Zhang H, et al. (2020) Alveolar macrophage dysfunction and cytokine storm in the pathogenesis of two severe COVID-19 patients. EBioMedicine 57: 102833. [Crossref]

63. Jin X, Lian JS, Hu JH, Gao J, Zheng L, et al. (2020) Epidemiological, clinical and virological characteristics of 74 cases of coronavirus-infected disease 2019 (COVID-19) with gastrointestinal symptoms. Gut 69: 1002-1009. [Crossref]

64. Xu X, Han M, Li T, Sun W, Wang D, et al. (2020) Effective treatment of severe COVID-19 patients with tocilizumab. Proc Natl Acad Sci U S A 117: 10970-10975. [Crossref]

65. Abdennour, L., Zeghal, C., Deme, M. and Puybasset, L., 2012, June. Interaction brainlungs. In Annales francaises d'anesthesie et de reanimation (Vol. 31, No. 6, p. e101).

66. Dar KA, Iqbal N, Mushtaq A (2017) Intolerance of uncertainty, depression, and anxiety: Examining the indirect and moderating effects of worry. Asian $J$ Psychiatr 29: 129-133. [Crossref]

67. Mumtaz F, Khan MI, Zubair M, Dehpour AR (2018) Neurobiology and consequences of social isolation stress in animal model-A comprehensive review. Biomed Pharmacother 105: 1205-1222. [Crossref]

68. Wu P, Fang Y, Guan Z, Fan B, Kong J, et al. (2009) The psychological impact of the SARS epidemic on hospital employees in China: exposure, risk perception, and altruistic acceptance of risk. Can J Psychiatry 54: 302-311. [Crossref]

69. National Health Commission of China (2020) Guidelines for psychological assistance hotlines during 2019-nCoV Pneumonia epidemic (in Chinese).

70. Williams B (2020) Mental Health Concerns Arise Amid COVID-19 Epidemic. data dostępu 03-26.

71. Yang Y, Li W, Zhang Q, Zhang L, Cheung T, et al. (2020) Mental health services for older adults in China during the COVID-19 outbreak. Lancet Psychiatry 7: e19. [Crossref]

72. Liem A, Wang C, Wariyanti Y, Latkin CA, Hall BJ (2020) The neglected health of international migrant workers in the COVID-19 epidemic. Lancet Psychiatry 7: e20. [Crossref]

73. Duan L, Zhu G (2020) Psychological interventions for people affected by the COVID-19 epidemic. Lancet Psychiatry 7: 300-302. [Crossref]

74. Taquet M, Luciano S, Geddes JR, Harrison PJ (2021) Bidirectional associations between COVID-19 and psychiatric disorder: retrospective cohort studies of 62354 COVID-19 cases in the USA. Lancet Psychiatry 8: 130-140. [Crossref]

75. Gammon J, Hunt J, Musselwhite C (2019) The stigmatisation of source isolation: a literature review. $J$ Res Nursing 24: 677-693.

76. Shah M, Sachdeva M, Dodiuk-Gad RP (2020) COVID-19 and racial disparities. J Am Acad Dermatol 83: e35. [Crossref]

77. Sim M (2016) Psychological trauma of Middle East Respiratory Syndrome victims and bereaved families. Epidemiol Health 38: e2016054. [Crossref]
78. Troyer EA, Kohn JN, Hong S (2020) Are we facing a crashing wave of neuropsychiatric sequelae of COVID-19? Neuropsychiatric symptoms and potential immunologic mechanisms. Brain Behav Immun 87: 34-39. [Crossref]

79. Zandifar A, Badrfam R (2020) Iranian mental health during the COVID-19 epidemic. Asian J Psychiatr 51: 101990. [Crossref]

80. Badrfam R, Zandifar A (2020) COVID-19 and Mental Health: An Iranian Perspective. Asian J Psychiatr 54: 102266. [Crossref]

81. Park SC, Park YC (2020) Mental Health Care Measures in Response to the 2019 Novel Coronavirus Outbreak in Korea. Psychiatry Investig 17: 85-86. [Crossref]

82. Brooks SK, Webster RK, Smith LE, Woodland L, Wessely S, et al. (2020) The psychological impact of quarantine and how to reduce it: rapid review of the evidence. Lancet 395: 912-920. [Crossref]

83. Tang W, Hu T, Hu B, Jin C, Wang G, et al. (2020) Prevalence and correlates of PTSD and depressive symptoms one month after the outbreak of the COVID-19 epidemic in a sample of home-quarantined Chinese university students. J Affect Disord 274: 1-7. [Crossref]

84. Hawryluck L, Gold WL, Robinson S, Pogorski S, Galea S, et al. (2004) SARS control and psychological effects of quarantine, Toronto, Canada. Emerg Infect Dis 10: 12061212. [Crossref]

85. Sellner J, Jenkins TM, von Oertzen TJ, Bassetti CL, Beghi E, et al. (2021) A plea for equitable global access to COVID-19 diagnostics, vaccination and therapy: The NeuroCOVID-19 Task Force of the European Academy of Neurology. Eur J Neurol. [Crossref]

86. Segrin C (2019) Indirect effects of social skills on health through stress and loneliness. Health commun 34: 118-124. [Crossref]

87. Daviu N, Bruchas MR, Moghaddam B, Sandi C, Beyeler A (2019) Neurobiological links between stress and anxiety. Neurobiol stress 11: 100191. [Crossref]

88. Chong MY, Wang WC, Hsieh WC, Lee CY, Chiu NM, et al. (2004) Psychological impact of severe acute respiratory syndrome on health workers in a tertiary hospital. $\mathrm{Br}$ J Psychiatry 185: 127-133. [Crossref]

89. Lee SM, Kang WS, Cho AR, Kim T, Park JK (2018) Psychological impact of the 2015 MERS outbreak on hospital workers and quarantined hemodialysis patients. Compr Psychiatry 87:123-127. [Crossref]

90. Mohammed A, Sheikh TL, Gidado S, Poggensee G, Nguku P, et al. (2015) An evaluation of psychological distress and social support of survivors and contacts of Ebola virus disease infection and their relatives in Lagos, Nigeria: a cross sectional study--2014. BMC Public Health 15: 824. [Crossref]

91. Chen Q, Liang M, Li Y, Guo J, Fei D, et al. (2020) Mental health care for medical staff in China during the COVID-19 outbreak. Lancet Psychiatry 7: e15-e16. [Crossref]

92. Liu S, Yang L, Zhang C, Xiang YT, Liu Z, et al. (2020) Online mental health services in China during the COVID-19 outbreak. Lancet Psychiatry 7: e17-e18. [Crossref]

93. Wang Y, Di Y, Ye J, Wei W (2019) Study on the public psychological states and its related factors during the outbreak of coronavirus disease 2019 (COVID-19) in some regions of China. Psychol Health Med 26: 13-22. [Crossref]

94. Naeem F, Irfan M, Javed A (2020) Coping with covid-19: urgent need for building resilience through cognitive behaviour therapy. Khyber Med Univ J 12: 1-3.

95. Richardson R, Dale HE, Wellby G, McMillan D, Churchill R (2018) Mental Health First Aid as a tool for improving mental health and well-being. The Cochrane Database of Systematic Reviews.

96. Kitchener BA, Jorm AF (2006) Mental health first aid training: review of evaluation studies. Aust N Z J Psychiatry 40: 6-8. [Crossref]

97. Langlands RL, Jorm AF, Kelly CM, Kitchener BA (2008) First aid for depression: a Delphi consensus study with consumers, carers and clinicians. J Affect Disord 105: 157-165. [Crossref]

98. Kelly CM, Jorm AF, Kitchener BA (2009) Development of mental health first aid guidelines for panic attacks: a Delphi study. BMC psychiatry 9: 49.

99. Ross AM, Kelly CM, Jorm AF (2014) Re-development of mental health first aid guidelines for non-suicidal self-injury: a Delphi study. BMC Psychiatry 14: 236 [Crossref]

100. Hart LM, Mason RJ, Kelly CM, Cvetkovski S, Jorm AF (2016) 'teen Mental Health First Aid': a description of the program and an initial evaluation. Int J Ment Health Syst 10: 3. [Crossref] 
Harricharan R (2021) The neuropsychological impact of the CoVID-19 pandemic on the mental wellbeing of individuals - what have we learnt thus far

101. Coyle D, McGlade N, Doherty G, O'Reilly G (2011) Exploratory evaluations of a computer game supporting cognitive behavioural therapy for adolescents. Proceedings of the SIGCHI Conference on Human Factors in Computing Systems 2937-2946.

102. Bond KS, Jorm AF, Kitchener BA, Reavley NJ (2016) Mental health first aid training for Australian financial counsellors: an evaluation study. Adv Mental Health 14: 65-74.

103. Aiello A, Khayeri MY, Raja S, Peladeau N, Romano D, et al. (2011) Resilience training for hospital workers in anticipation of an influenza pandemic. J Contin Educ Health Prof 31: 15-20. [Crossref]
104. Everly GS Jr, Flynn BW (2006) Principles and practical procedures for acute psychological first aid training for personnel without mental health experience. Int $J$ Emerg Ment Health 8: 93-100. [Crossref]

105. Everly GS Jr, Lee McCabe O, Semon NL, Thompson CB, Links JM (2014) The development of a model of psychological first aid for non-mental health trained public health personnel: the Johns Hopkins RAPID-PFA. J Public Health Manag Pract 20: S24-S29. [Crossref]

106. Birkhead GS, Vermeulen K (2018) Sustainability of Psychological First Aid Training for the Disaster Response Workforce. Am J Public Health 108: S381-S382. [Crossref]

Copyright: (C2021 Harricharan R. This is an open-access article distributed under the terms of the Creative Commons Attribution License, which permits unrestricted use, distribution, and reproduction in any medium, provided the original author and source are credited. 